\title{
KEMAMPUAN MEMBACA PEMAHAMAN CERITA PENDEK MELALUI MODEL PEMBELAJARAN KOOPERATIF TIPE STUDENT TEAM ACHIEVEMENT DIVISION (STAD) PADA SISWA MADRASAH IBTIDAIYAH \\ Oleh Yuliwati
}

MI Hijriyah 6 Palembang Yuliwatipps@yahoo.co.id

\begin{abstract}
Abstrack: Background in this research is learning comprehension reading never increase because using conventional method. The formulation of the problem in this research is 1) How is the model of cooperative learning model Student Team Achievement Division (STAD) can improve students ability in reading comprehension of short story?; and 2) How is the result of improving students ability in reading comprehension of short story by using STAD type cooperative learning model ?. The research method used is Classroom Action Research (PTK). Technique of collecting data in this research use Observation and test. The conclusion of the research result shows that the application of Cooperative STAD type learning model can improve reading comprehension ability in the students of Grade $V$ of Madrasah Ibtidaiyah Hijriyah 6 Palembang. In cycle 1 only 4 people (13.33\%) of the students who complete the value of $K K M 75$, and the remaining 26 people (86.67\%) did not reach KKM 75 . In cycle II showed that 18 people (60.00\%) students who (KKM 75) did not reach KKM 75. In the third cycle, the students who complete the KKM 75 score of 29 (96.67) and the rest only 1 person $(3.33 \%)$ did not reach KKM 75. This means that the achievement rate of learning achievement of $85 \%$ is categorized as successful and does not need further action of the next cycle.
\end{abstract}

Keywords: reading comprehension, STAD type cooperative learning model, short story

\section{PENDAHULUAN}

Bahasa merupakan alat yang sangat penting bagi manusia dalam berkomunikasi, manusia berkomunikasi agar bisa saling belajar, dan dapat meningkatkan kemampuan intektualnya.

Ketrampilan berbahasa ada empat macam, yakni menyimak, berbicara, membaca, dan menulis. Keempat keterampilan tersebut memiliki perananan yang sangat penting dalam berbagai kesempatan. Ketrampilan membaca merupakan salah satu ketrampilan yang harus di berikan dan diajarkan pada siswa, hal ini sangat penting yang harus dimiliki oleh siswa dalam preoses pembelajaran (Tarigan, 2015:8).

Membaca merupakan suatu
proses yang dilakukan serta
dipergunakan oleh pembaca untuk
memperoleh pesan yang hendak
disampaikan oleh penulis melalui katakata atau bahasa tulis (Tarigan, 2015:7). Menurut Dalman (2014:5), membaca 
merupakan suatu kegiatan atau proses kognitif yang berupaya untuk menemukan berbagai informasi yang terdapat dalam tulisan. Dengan membaca, kita dapat mengetahui dan menguasai berbagai hal. Banyak orang membaca kata demi kata, bahkan mengucapkannya secara cermat, dengan maksud dapat memahami isi bacaannya. Membaca kata demi kata memang bermanfaat, tetapi tidak cocok untuk semua tujuan

Menurut Tampubolon (2015:5), membaca adalah satu dari empat kemampuan bahasa pokok, merupakan suatu kegiatan dari komunikasi lisan. Untuk memperoleh informasi tersebut perlu kemampuan dalam membaca, salah satunya adalah kemampuan membaca pemahaman.

Bahasa Indonesia memiliki empat indikator yang harus dikuasai siswa dalam berkomunikasi yaitu; mendengarkan, berbicara, membaca dan menulis Membaca adalah suatu proses yang dilakukan serta dipergunakan oleh pembaca untuk memperoleh pesan, yang hendak disampaikan oleh penulis melalui media kata kata atau bahsa tulis. Suatu proses yang menuntut agar kelompok katayang merupakan suatu kesatuan akan terlihat dalam suatu pandangan sekilas, dan agar makna katakata secara individual akan dapat diketahui Kalau hal ini tidak terpenuhi, maka pesan tersurat dan yang tersirat tidak akan tertangkap atau dipahami, dan proses membaca itu tidak terlaksana dengan baik (Tarigan,2008:4).

Cerpen merupakan sebuah karya yang di dalamnya terkandung berbagai aspek kehidupan, termasuk didalamnya adalah pendidikan. Cerpen dapat mempengaruhi kehidupan sesorang, atau sikap seseorang bahkan dapat terbangun melalui sebuah cerpen. Cerpen adalah salah satu bagian dari sastra. Pembelajaran kooperatif merupakan salah satu modelpembelajaran kelompok yang memiliki aturan-aturan tertentu. Prinsip dasar pembelajaran kooperatif adalah siswa membentuk kelompok kecil dan saling mengajar sesamanya untuk mencapai tujuan bersama. Dalam pembelajaran kooperatif siswa pandai mengajarkan siswa yang kurang pandai tanpa merasa dirugikan. Siswa yang sebelumnya bersikap pasif akan berpartisipasi secara aktif agar dapat diterima dalam kelompok setelah menggunakan pembelajaran kooperatif (Trianto, 2009:55).

Secara aktif adalah dengan menerapkan model pembelajaran kooperatif tipe Stundent Team Achievement Division (STAD). Pembelajaran ini bermaksud guru yang menyajikan materi terlebih dahulu, kemudian dilanjutkan dengan siswa mengerjakan dalam bentuk kelompok 
yang terdiri dari atas empat sampai lima anggota yang berbentuk heterogen. Setelah kegiatan kelompok dilakukan, maka setiap siswa kuis atau tes individual. Namun, dalam mengerjakan kuis, setiap siswa harus bekerja secara individual dan diakhiri dengan tahap pemberian penghargaan bagi setiap kelompok yang berprestasi didasarkan pada rata-rata skor perkembangan siswa dalam kelompok. Ide yang paling utama dalam model kooperatif tipe STAD ini adalah memotivasi siswa untuk mendorong dan saling membantu di antara siswa dalam menguasai ketrampilan atau pengetahuan yang disajikan oleh guru.

Model pembelajaran ini dikembangkan oleh Slavin dan temantemannya di Universitas Jgon Hopkin. Siswa dalam satu kelas dipecah menjadi kelompok masing-masing 4--5 orang. Model ini merupakan model pembelajaran yang paling sederhana, guru yang menggunakan metode ini mengacu pada kepada kelompok belajar siswa, menyajikan informasi berkaitan dengan akademik baru kepada siswa dengan menggunaka presentasi verbal dan teks (Hamdayama, 2015:115).

Berdasarkan hasil observasi awal yang dilakukan peneliti pada semester ganjil tahun ajaran 2016/2017 di Madrasah Ibtidaiyah Hijriyah 6 Palembang, masih banyak siswa membaca dengan: (1) menunjuk kata demi kata, (2) mengeluarkan suara, (3) mulut bergerak-gerak, (4) menggerakan kepala dari kiri ke kanan, dan (5) mengulang kata yang sudah dibaca.

Selain itu, Kriteria Ketuntasan Minimal (KKM) mata pelajaran bahasa Indonesia di Madrasah Ibtidaiyah Hijriyah 6 Palembang adalah 75. Siswa dinyatakan mampu membaca dengan baik jika mendapat nilai $\geq 75$, sedangkan siswa yang kurang $\leq 75$. Uraian diatas dengan jelas menerangkan bahwa kemampuan membaca dan memahami cerita pendek dengan siswa kelas $\mathrm{V}$ Madrasah Ibtidaiyah Hijriyah 6 Palembang. Saat ini masing cenderung rendah. Perlu adanya solusi dalam penanganan masalah tersebut.

Dari fakta di atas, maka perlu diupayakan kualitas pembelajaran untuk meningkatkan kemampuan anak terhadap pemahaman bacaan yang dibaca. Jalan yang dapat ditempuh adalah dengan penggunaan berbagai strategi pembelajaran membaca yang dapat melatih siswa memaknai dari setiap bacaan yang dibacanya, serta memilih materi yang sesuai dan disenangi oleh anak. Secara naluriah, setiap anak senang dengan cerita atau dongeng karena berkembangnya kemampuan berbicara anak semakin menuntut keingintahuan mereka akan banyak hal dengan cara membaca cerita. 
Akan tetapi kegiatan membaca cerita sudah mulai jarang dilakukan anak karena sudah tergantikan oleh film-film di televisi, permainan permainan di internet atau kegiatan lainnya yang lebih banyak disukai anak dibanding kegiatan membaca cerita. Padahal, membaca cerita atau membaca dongeng dapat membangun dan mengembangkan kepribadian anak. Pembelajaran membaca cerita yang dilakukan di sekolah dasar pada umumnya masih menggunakan metode konvensional (ceramah).

Berdasarkan pengamatan yang dilakukakan oleh peneliti lakukan terhadap siswa ketika sedang mengikuti proses pembalajaran bahasa Indonesia, dapat dikatakan bahwa siswa kurang termotivasi atau pasif. Terutama pada pembelajaran membaca pemahaman terhadap cerpen. Hal ini juga, didukung dengan pengalaman peneliti yang mengajar selama 5 tahun sebagai Guru Bahasa Indonesia kelas V di sekolah M.I Hijriyah 6 Palembang, siswa pada materi pembelajaran membaca pemahaman tidak pernah meningkat karena pada umumnya pada pembelajaran membaca pemahaman khususnya sebuah cerpen masih menggunakan metode konvensional yang menyebabkan tingkat ketuntasan masih sangat rendah. Hal ini ditunjukan dengan nilai rata-rata yang diperoleh siswa untuk membaca pemahaman pada tahun 2016/2017 hanya 45 sedangkan KKM yang harus dipenuhi sebesar 75 .

Untuk memperbaiki hal ini yang dilakukan oleh guru adalah dengan menerapkan suatu model pembelajaran yang tepat untuk meningkatkan proses belajar mengajar dengan menggunakan model pembelajaran kooperatif tipe STAD.

Dengan menggunakan model kooperatipe tipe Student Team Achievement Division (STAD) dapat menciptakan suasana belajar menjadi efektif dan aktif. Oleh sebab itu peneliti memilih model pembelajaran kooperatipe tipe Student Team Achievement Division (STAD) siswa kelas V M.I. Hijriyah 6 Palembang. Penelitian ini menggunakan metode tindakan kelas (PTK) dengan judul "Peningkatan Kemampuan Membaca dan Memahami Cerita Pendek Melalui Model Pembelajaran kooperatif Tipe Student Team Achievement Division (STAD) pada Siswa Kelas V Madrasah Ibtidaiyah Hijriyah 6 Palembang”.

\section{METODOLOGI PENELITIAN}

Tujuan penelitian ini adalahuntuk meningkatkan kemampuan membaca pemahaman melaui model Pembelajaran Kooperatif Tipe STAD pada siswa kelas V MI. Hijriyah 6 Palembang. Sejalan dengan itu tujuan 
khusus penelitian ini adalah sebagai berikut.

1. Untuk mengetahui proses model pembelajaran kooperatif tipe Student Team Achievement Division (STAD) dapat meningkatkan kemampuan siswa dalam membaca pemahaman cerita pendek pada siswa kelas V Madrasah Ibtidaiyah Hijriyah 6 Palembang

2. Untuk mengetahui hasil peningkatan kemampuan siswa dalam membaca pemahaman cerita pendek pada siswa kelas V Madrasah Ibtidaiyah Hijriyah 6 Palembang dengan menggunakan metode pembelajaran kooperatif tipe Student Team Achievement Division (STAD)

Objek penelitian ini adalah siswa Kelas V Madrasah Ibtidaiyah Hijriyah 6 Palembang tahun pelajaran 2016/2017 yang berjumlah siswa terdiri 15 siswa laki-laki dan 15 siswa perempuan. Penelitian ini dilaksanakan di Madrasah Ibtidaiyah Hijriyah 6 Palembang dan dilaksanakan pada tanggal 24 April 2017 sampai dengan 31 Mei 2017. Waktu penelitian adalah pada jam pelajaran bahasa Indonesia sedang berlangsung di Kelas V Madrasah Ibtidaiyah Hijriyah 6 Palembang.
Metode penelitian yang digunakan dalam penelitian ini adalah penelitian Tindakan Kelas (classroom action research) yaitu model John Elliot; apabila dibandingkan dua model yang sudah diutarakan di atas, yaitu Model Kurt Lewin dan KemmisMcTaggart, PTK Model John Elliot dikutip Aqib (2011:23) ini tampak lebih detail dan rinci. Dikatakan demikian, oleh karena di dalam setiap siklus dimungkinkan terdiri dari beberapa aksi yaitu antara 3-5 aksi (tindakan).

Sementara itu, setiap aksi kemungkinan terdiri dari beberapa langkah, yang terealisasi dalam bentuk kegiatan belajar-mengajar. Maksud disusunnya secara terinci pada PTK Model John Elliot ini, supaya terdapat kelancaran yang lebih tinggi antara taraf-taraf di dalam pelaksanan aksi atau proses belajarmengajar. Selanjutnya, dijelaskan pula olehnya bahwa terincinya setiap aksi atau tindakan sehingga menjadi beberapa langkah oleh karena suatu pelajaran terdiri dari beberapa subpokok bahasan atau materi pelajaran. Di dalam kenyataan praktik di lapangan setiap pokok bahasan biasanya tidak akan dapat diselesaikan dalam satu langkah, tetapi akan diselesaikan dalam beberapa rupa itulah yang menyebabkan John Elliot menyusun model PTK yang berbeda 
secara skematis dengan kedua model

dikemukakan berikut ini.

sebelumnya, yaitu seperti

\section{SIKLUS PELAKSANAAN PTK}

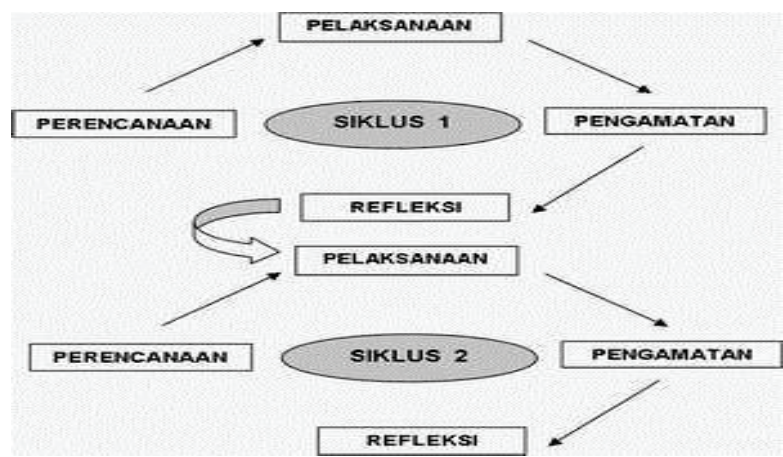

Gambar 4: Riset Aksi Model John Elliot (Arikunto, 2014:137)

\section{HASIL PEMBAHASAN}

\section{A. Hasil Penelitian}

Berdasarkan nilai rata rata tes kemampuan membaca pemahaman cerpen pada siklus III mengalami peningkatan dibandingkan siklus I dan siklus II. Peningkatan tersebut telah mencapai $85 \%$ ketuntasan siswa dengan KKM 75. Artinya,taraf kemampuan siswa rata rata indikator yang dilaksanakan telah berhasil. Oleh karenaa itu, peneliti tidak perlu melakukan tindakan lanjutan untuk meningkatkan kemampuan membaca pemahaman cerita pendek pada siswa kelas V Madrasah Ibtidaiyah Hijriyah 6 Palembang . 
Tabel 4.19

Perbandingan Hasil Pembelajaran Membaca Pemahaman melalui Model Pembelajaran Kooperatif Tipe Student Team Achievement Division (STAD) pada Siklus I dengan Siklus II dan Siklus III

\begin{tabular}{|c|c|c|c|c|}
\hline No. & Nama siswa & Siklus I & Siklus II & Siklus III \\
\hline 1. & Athaya Putri F & 82,15 & 79,15 & 82,21 \\
\hline 2. & Laura Chika P & 67,57 & 70,00 & 76,57 \\
\hline 3. & Dwi nia A & 73,43 & 72,86 & 76,08 \\
\hline 4. & Tia ramadhani & 65,71 & 77,15 & 82,88 \\
\hline 5. & Azizah badriah & 55,71 & 76,43 & 78,16 \\
\hline 6. & Chaty Nur R & 84,29 & 80,00 & 80,55 \\
\hline 7. & Kaila Aqis S & 65,71 & 83,58 & 79,62 \\
\hline 8. & Nazwa Meriska & 50,00 & 68,57 & 80,55 \\
\hline 9. & Meri Wahyu R & 67,14 & 68,57 & 79,21 \\
\hline 10. & Silva saputri & 62,85 & 62,86 & 77,65 \\
\hline 11. & Della adha & 83,57 & 81,43 & 78,18 \\
\hline 12. & Cantika sari & 61,43 & 80,00 & 81,43 \\
\hline 13. & Karina & 80,72 & 67,57 & 63,91 \\
\hline 14. & Dwi Citra lestari & 60,00 & 76,43 & 80,49 \\
\hline 15. & Hamdani & 73,57 & 70,50 & 79,04 \\
\hline 16. & M. Farhn & 50,00 & 77,24 & 81,15 \\
\hline 17. & M. Azha W & 68,57 & 77,86 & 77,64 \\
\hline 18. & Dwi sastri & 55,71 & 80,72 & 83,52 \\
\hline 19. & Hariansyah & 65,71 & 84,29 & 78,57 \\
\hline 20. & M. Farel & 49,86 & 79,29 & 80,50 \\
\hline 21. & Feri & 51,43 & 67,57 & 77,40 \\
\hline 22. & M. Agung & 67,14 & 70,00 & 77,29 \\
\hline 23. & Bagaskara & 60,00 & 62,86 & 78,03 \\
\hline 24. & Bagus Afriansyah & 65,71 & 77,86 & 80,50 \\
\hline 25. & M. Arafah & 54,29 & 68,58 & 82,52 \\
\hline 26. & Raymond Tirta & 68,57 & 81,43 & 77,14 \\
\hline 27. & Vardo & 48,57 & 77,14 & 79,56 \\
\hline 28. & Bagus Afriansyah & 65,71 & 71,58 & 82,16 \\
\hline 29 & Winata & 49,57 & 77,86 & 79,99 \\
\hline \multirow[t]{5}{*}{30} & Yusuf Tirta & 53,34 & 77,22 & 81,51 \\
\hline & Jumlah & 1908,03 & 2246,6 & 2374,01 \\
\hline & Rata rata & 63,601 & 74,87 & 79,13 \\
\hline & Pencapaian KKM(75) & 4 & 18 & 29 \\
\hline & Persentase & $13,33 \%$ & $60,00 \%$ & $96,67 \%$ \\
\hline
\end{tabular}

Secara jelas, perbandingan persentase ketuntasan klasikal kemampuan membaca pemahaman cerita pendek siswa kelas V Madrasah Ibtidaiyah
Hijriyah 6 Palembang pada siklus 1, siklus II dan sikulus III dapat dilihat pada tabel berikut. 
Tabel 4.20

Perbandingan Tingkat Pencapaian Kriteria Ketuntasan Minimum (KKM 75) pada siswa kelas V

Madrasah Ibtidaiyah Hijriyah 6 Palembang

\begin{tabular}{|c|c|c|c|c|c|c|}
\hline $\begin{array}{c}\text { Pencapaian } \\
\text { Nilai KKM } \\
\mathbf{7 5}\end{array}$ & $\begin{array}{c}\text { Siklus } \\
\mathbf{1}\end{array}$ & Presentase & $\begin{array}{c}\text { Siklus } \\
\mathbf{2}\end{array}$ & Presentase & $\begin{array}{c}\text { Siklus } \\
\mathbf{3}\end{array}$ & Presentase \\
\hline $\begin{array}{c}\text { Siswa yang } \\
\text { tuntas }\end{array}$ & 4 & $13,33 \%$ & 18 & $60,00 \%$ & 29 & $96,67 \%$ \\
\hline $\begin{array}{c}\text { Siswa yang } \\
\text { tidak tuntas }\end{array}$ & 26 & $86,67 \%$ & 12 & $40,00 \%$ & 1 & 3,33 \\
\hline Jumlah & $\mathbf{3 0}$ & $\mathbf{1 0 0} \%$ & $\mathbf{3 0}$ & $\mathbf{1 0 0 \%}$ & $\mathbf{2 0}$ & $\mathbf{1 0 0 \%}$ \\
\hline
\end{tabular}

Berdasarkan tabel di atas, menunjukkan bahwa pada siklus 1 hanya 4 orang $(13,33 \%)$ siswa yang tuntas mencapai nilai Kriteria Ketuntasan Minimum (KKM 75), dan sisanya 26 orang $(86,67 \%)$ tidak mencapai Kriteria Ketuntasan Minimum (KKM 75). Hal ini berarti bahwa tingkat pencapaian keberhasilan belajar sebesar $85 \%$ dikategorikan tidak berhasil dan harus dilajutkan pada siklus II. Pada siklus II menunjukkan bahwa 18 orang $(60,00 \%)$ siswa yang tuntas mencapai nilai Kriteria Ketuntasan Minimum (KKM $75)$, dan sisanya 12 orang $(40,00 \%)$ tidak mencapai Kriteria Ketuntasan Minimum (KKM 75). Hal ini berarti bahwa tingkat pencapaian keberhasilan belajar sebesar $85 \%$ dikategorikan tidak berhasil dan harus dilajutkan pada siklus II. Selanjutnya, pada siklus III, hampir seluruh siswa yang tuntas mencapai nilai Kriteria Ketuntasan Minimum (KKM $75)$ yakni sebanyak 29 orang $(96,67 \%)$, dan sisanya hanya 1 orang $(3,33 \%)$ tidak mencapai Kriteria Ketuntasan Minimum (KKM 75). Hal ini berarti bahwa tingkat pencapaian keberhasilan belajar sebesar $85 \%$ dikategorikan telah berhasil dan tidak perlu tindakan lanjut siklus berikutnya. Untuk lebih terinci dapat disajikan pada diagram berikut. 


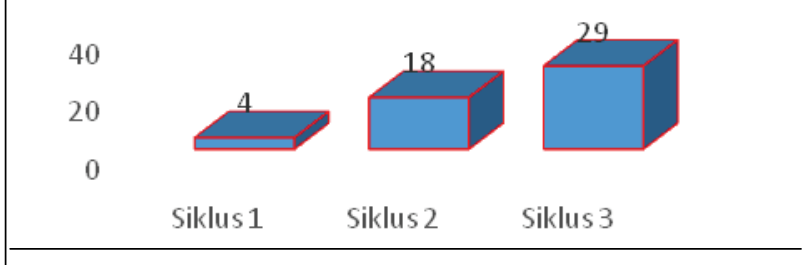

Gambar 4.1

Diagram Perbandingan Persentase Ketuntasan Klasikal Kemampuan Membaca Pemahaman Cerita Pendek Siswa Kelas V Madrasah Ibtidaiyah Hijriyah 6 Palembang pada Siklus 1, Siklus 11 dan siklus III

Berdasarkan uraian di atas maka peneliti tidak melanjutkan pada tindakan berikutnya. Hal ini dikarenakan telah tercapainya hasil Kemampuan Membaca Pemahaman Cerita Pendek Siswa Kelas V Madrasah Ibtidaiyah Hijriyah 6 Palembang. Pada siklus III guru telah menerapkan belajar aktif dan mandiri dengan baik dan di lihat dari aktivitas siswa serta hasil belajar siswa pelaksanaan hasil proses belajar mengajar sudah berjalan dengan baik. Maka tidak diperlukan revisi lagi, tetapi yang perlu diperhatikan untuk tindakan selanjutnya adalah memaksimalkan dan mempertahankan apa yang telah ada dengan tujuan agar pada pelaksanaan proses belajar mengajar selanjutnya penerapan belajar aktif dapat meningkatkan proses belajar mengajar sehingga tujuan pembelajaran dapat di capai.

\section{B. Pembahasan Hasil Penelitian}

Berdasarkan hasil penelitian yang di lakukan dalam tiga siklus di peroleh hasil bahwa kemampuan membaca pemahaman cerita pendek pada siswa kelas V Madrasah Ibtidaiyah Hijriyah 6 Palembang mengalami peningkatan setelah diterapkannya model pembelajaran kooperatif tipe Student Team Achievement Division (STAD). Perlakuan PTK ini di lakukan dalam dua siklus sebab pada siklus pertama hasil kemampuan membaca pemahaman yang di peroleh belum mencapai ketuntasan minimal.

Sejalan dengan hal diatas, didukung oleh penelitian terdahulu yang relevan dilakukan oleh Gregorius Jala (2014) menunjukkan bahwa melalui penerapan model pembelajaran kooperatif tipe Student Team Achievement Division (STAD) di SMP PGRI 6 Denpasar terhadap kemampuan memahami unsur-unsur intrinsik cerpen mengalami peningkatan. Selain itu, penelitian ini sejalan dengan penelitian relevan yang dilakukan oleh Basuni (2009), hasil penelitian menunjukkan bahwa 
kemampuan membaca lancar pada mata pelajaran Bahasa Indonesia melalui model pembelajaran kooperatif tipe Student Team Achievement Division (STAD) siswa kelas 1 MI An-Nuriyah 1 dapat meningkat. Ini disebabkan karena aktivitas siswa dalam proses belajar mengajar mulai dari siklus I sampai ke siklus III terus mengalami peningkatan.

Secara klasikal peningkatan
siswa dalam membaca pemahaman
cerita pendek melalui model
pembelajaran kooperatif tipe Student

Team Achievement Division (STAD) sudah menunjukan peningkatan yang cukup memuaskan. Peningkatan hasil belajar siswa tidak terlepas dari dorongan guru dan keantusiasan siswa belajar sangat besar.guru sebagai pelaksanaan tindakan telah melakukan perubahan dalam cara mengajarnya. Akan tetapi pada penelitian ini guru telah mengadakan perubahan dalam cara mengajarnya di samping memberikan teori tentang kemampuan Membaca Pemahaman Cerita Pendek pada siswa melalui model pembelajaran kooperatif tipe Student Team Achievement Division (STAD), juga memberikan waktu dan kesempatan kepada siswa untuk mengekplorasi, kolaborasi, serta berelaborasi sehingga siswa dapat meningkatkan kemampuannya dalam memahami suatu cerpen.
Di samping itu, guru juga telah menemukan langkah-langkah model pembelajaran kooperatif tipe Student Team Achievement Division (STAD)yang diterapkan sehingga nilai yang ditargetkan oleh penulis dapat tercapai, sebagai berikut. (a) membuka pelajaran dan mengabsen kehadiran siswa, (b) memberikan aprsepsi terkait dengan pembelajaran yang akan dilaksanakan, (c) menyampaikan tujuan pembelajaran, (d) memberikan orientasi materi pelajaran beserta pembelajaran yang akan diterapkan, (e) mengarah siswa untuk membentuk kelompok sebanyak 7 kelompok masing-masih terdiri dari 5 orang sampai 6 orang, (f) membagikan satu judul cerpen kepada siswa untuk didiskusikan dalam masing-masing kelompok, (g) mengawasi diskusi kelompok kecil, (h) memberikan kesempatan bertanya bagi siswa yang mengalami kesulitan dalam pembelajaran, (i) memilih perwakilan dari kelompok untuk menceritakan kembali isi cerpen yang telah dibacanya ke depan kelas, (j) mengawasi hasil kerja kelompok dalam Kemampuan Membaca Pemahaman Cerita Pendek, (k) bersama-sama siswa untuk menyimpulkan dan menrefleksi hasil serta pelaksanaan pembelajaran yang telah dilakukan daan memberikan penghargaan bagi siswa yang hasil 
kerjanya mendapat nilai paling baik, dan (l) menutup pelajaran.

Aspek aspek yang mendapat penilaian kurang baik tersebut, merupakan suatu kelemahan yang terjadi pada siklus 1.Penyebab yang menentukan keberhasilan dalam peningkatan kemampuan membaca pemahaman adalah pengkodisian kelas atau situasi pembelajaran dan proses ketika membaca. Sebab, membaca merupakan jenis kemampuan membaca pemahaman manusia sebagai produk belajar dari lingkungan, dan bukan kemampuanbersifat inisiatif atau naluri yang di bawa sejak lahir (Nurhadi,2010;123).

Pada siklus III telah memenuhi kriteria yang telah ditetapkan dan sudah berhasil dan tidak perlu melakukan tindakan lebih lanjut. Hal ini sejalan dengan penelitian relevan yang dilakukan oleh Maryadi (2013), hasil penelitiannya menunjukkan bahwa penerapan model pembelajaran kooperatif tipe Student Team Achievement Division (STAD) dapat meningkkatkan kemampuan siswa dalam menulis surat dinas. Selain itu, penelitian yang dilakukan oleh Yusman, dkk (2015), hasil penelitian menunjukkan bahwa melalui model pembelajaran kooperatif tipe STAD dapat meningkatkan hasil belajar siswa pada mata pelajaran bahasa Indonesia di kelas V SDN 25 Ampana pada tema membaca. Selanjutnya, didukung juga oleh penelitian relevan yang dilakukan oleh Nafisah (2011), hasil penelitian menunjukkan adanya peningkatan nilai rata-rata pemahaman siswa terhadap unsur intrinsik pada cerpen melalui model pembelajaran kooperatif tipe Student Team Achievement Division (STAD).

Berkaitan dengan uraian di atas, hal ini sesuai dengan pertanyaan Student Teams Achievement Division (STAD) ini dikembangkan oleh Slavin (2010:143), yang menekankan interaksi diantara siswa untuk saling memotivasi dan saling membantu dalam menguasai materi dan pencapaian prestasi secara maksimal, dan juga merupakan salah satu metode atau pendekatan dalam pembelajaran kooperatif yang sederhana dan baik untuk guru yang baru mulai menggunakan pendekatan kooperatif dalam kelas, STAD juga merupakan suatu metode pembelajaran kooperatif yang efektif. Penerapan pembelajaran kooperatif tipe STAD pada pelajaran membaca lancar tersebut dimungkinkan karena dengan penggunaan pembelajaran kooperatif tipe STAD dalam proses belajar-mengajar menjadikan pembelajaran lebih aktif dan menyenangkan. Siswa yang sudah bisa membaca dapat mengajari temannya yang belum dapat memahami 
dan membaca cerpen agar nantinya juga bisa membaca seperti dia dengan bimbingan guru. Sehingga siswa yang belum lancar membaca lebih termotivasi karena temannya sudah lancar membaca dan bahkan menjadi guru sebaya bagi mereka.

\section{SIMPULAN}

Berdasarkan hasil penelitian yang disajikan dalam Bab IV maka dapat disimpulkan sebagai berikut:

1. Penerapan model pembelajaran kooperatif Tipe Sudent Team Achievement Division (STAD) dapat meningkatkan kemampuan membaca pemahaman pada siswa Kelas V Madrasah Ibtidaiyah Hijriyah 6 Palembang

2. Penelitian ini dilakukan melalui tiga siklus. Pada siklus 1 hanya 4 orang $(13,33 \%)$ siswa yang tuntas mencapai nilai Kriteria Ketuntasan Minimum (KKM 75), dan sisanya 26 orang $(86,67 \%)$ tidak mencapai Kriteria Ketuntasan Minimum (KKM 75). Pada siklus II menunjukkan bahwa 18 orang $(60,00 \%)$ siswa yang tuntas mencapai nilai Kriteria Ketuntasan Minimum (KKM 75), dan sisanya 12 orang $(40,00 \%)$ tidak mencapai Kriteria Ketuntasan Minimum (KKM 75). Pada siklus III, hampir seluruh siswa yang tuntas mencapai nilai Kriteria Ketuntasan Minimum
(KKM 75) yakni sebanyak 29 orang $(96,67)$, dan sisanya hanya 1 orang $(3,33 \%)$ tidak mencapai Kriteria Ketuntasan Minimum (KKM 75). Hal ini berarti bahwa tingkat pencapaian keberhasilan belajar sebesar $85 \%$ dikategorikan telah berhasil dan tidak perlu tindakan lanjut siklus berikutnya.

\section{DAFTAR PUSTAKA}

\begin{tabular}{lrr} 
Aqib, & \multicolumn{1}{l}{ Zainal. 2014. } & Model-Model \\
Media & dan & Strategi \\
Pembelajaran & & Kontekstual \\
(Inovatif). & & Bandung:Yrama \\
Widia. & &
\end{tabular}

Arikunto Suharsimi. 2010. Prosedur Penelitian Suatu Pendekatan Praktik. Jakarta: PT. Rineka Cipta.

Dalman. 2014. Keterampilan Membaca. Jakarta: Kharisma Puta Utama.

Effendi, Thahar, Harris. 2009. Kiat Menulis Cerpen. Bandung: Percetakan Angkasa.

Hanafiah, Nanang dan Cucu Suhana. 2010. Konsep Strategi pembelajaran. Bandung: Refika Aditama.

Hamdayama. 2014. Model dan Metode Pembelajaran Kreatif dan Berkatakter. Jakarta: Ghalia Indonesia.

Huda, Miftahul. 2013. Cooperative Learning Metode, Teknik, Struktur dan Penerapan. Yogyakarta : Pustaka Pelajar. 
Isjoni. 2009. Cooperative Learning.

Bandung: Alfabeta.

Johnson, D.W., Johnson, R.T. \& Johnson-Holubec, E.J. 2010. Cooperation in the

Classroom. Bandung: Alfabeta.

Kosasih. 2016. Jenis-Jenis Teks Analisis

Fungsi, Struktur, dan Kaidah

Serta Langkah Penulisannya.

Bandung:Yrama Widya.

Kosasih.2012.

Dasar-Dasar

Keterampilan Bersastra.

Bandung: Yrama Widya.

Kurniasih, Imas dan Berlin Sani. 2016.

Ragam Pengembangan Model

Pembelajaran untuk

Meningkatkan Profesionalisme

Guru. Kata Pena.

Muryanto, Kristiawan. 2007. Aku Pandai Menulis Cerpen. Yogyakarta: Citra Aji Parama.

Nafisah, Durrah. 2011. Peningkatan Pemahaman Unsur Intrinsik pada Cerpen melalui Metode

Kooperatif Tipe Student Teams Achievement Division (STAD)

pada Siswa Kelas X MA AsSyafieciyah 01 Jakarta. Jakarta:

Universitas Islam Negeri Syarif Hidayatulah Jakarta (Tesis tidak diterbitkan)

Ngalimun. 2014. Strategi dan Model Pembelajaran.

Banjarmasin:Aswaja Pressindo

Nurhadi. 2008. Membaca Cepat dan Efektif. Bandung: Sinar Baru 
